\title{
Conjunctival Attachment of a Live Paralysis Tick, Ixodes holocyclus, in a Child: A Case Report
}

\author{
Joanne M.Y. Teong ${ }^{a} \quad$ Paul A. Adler ${ }^{a} \quad$ Stephen L. Doggett ${ }^{b}$ \\ Dariush Daneshvar ${ }^{c}$ Melissa K. Shields ${ }^{a}$ \\ ${ }^{\mathrm{a}}$ Parke Street Specialist Centre, Katoomba, N.S.W., Departments of ${ }^{\mathrm{b}}$ Medical Entomology \\ and ${ }^{\mathrm{C}}$ Tissue Pathology and Diagnostic Oncology, Westmead Hospital, Sydney, N.S.W., \\ Australia
}

\section{Key Words}

Tick · Ixodes holocyclus $\cdot$ Conjunctival attachment $\cdot$ Child $\cdot$ Excision

\begin{abstract}
We describe a rare clinical finding of conjunctival tick attachment in a child. A 10-year-old boy presented to the clinic with right-eye itch. He was found to have a live tick firmly attached to his right temporal conjunctiva. The tick was identified as the larval stage of the paralysis tick, Ixodes holocyclus. The tick was removed completely by conjunctival excision. Although various methods of removing a tick have been described in the literature, the goal of treatment is the safe and complete removal of the tick to prevent further transmission of pathogens, allergens, and toxins to the patient.

(c) 2015 S. Karger AG, Basel
\end{abstract}

\section{Introduction}

Conjunctival tick attachment is a rare occurrence, with only 7 cases reported in the literature. The tick species Ixodes holocyclus is found in Australia and belongs to the family of hard ticks, Ixodidae, which are a group of blood-sucking acarine ectoparasites [1,2]. It is also known as the paralysis tick because it produces a toxin that can cause motor paralysis, which is mainly a problem seen in veterinary medicine and rarely in humans, although children under 5 years of age are at greatest risk [3]. Ticks are known vectors of infectious diseases and are associated with a range of ocular and systemic conditions. We describe a rare- 
Teong et al.: Conjunctival Attachment of a Live Paralysis Tick, Ixodes holocyclus, in a Child: A Case Report

ly seen ophthalmic finding: conjunctival attachment of a live paralysis tick. We also discuss the literature regarding ocular tick attachment, clinical features, and management.

\section{Case Report}

A 10-year-old boy presented to the clinic with a 2-day history of right-eye redness and itch. The patient was visiting a property surrounded by bush land in the northern suburbs of Sydney, N.S.W., Australia. He felt a foreign body in his right eye after sitting on grass. A few hours later, he developed right-eye itch. He had no history of trauma. His only past medical history is mild Asperger syndrome. His visual acuity was $6 / 6$ in the right eye and $6 / 5$ in the left eye. Slit lamp examination revealed a live translucent-bodied organism with pulsatile fluid movement (at a different rate to the patient's heart), firmly attached to his right temporal bulbar conjunctiva (fig. 1a). There was conjunctival vessel dilatation surrounding the organism, but otherwise, ocular examination was unremarkable. Under general anaesthesia, the conjunctival tissue and the organism onto which it was attached (see arrow in fig. 1b) were elevated and excised en bloc. The excised area (approximately $3 \mathrm{~mm}$ in diameter) was left unclosed. The patient was started on a 1-week course of Chloramphenicol ophthalmic ointment and oral Cephalexin 4 times a day. The recovery of our patient, after 3 weeks, has so far been uneventful. The organism was examined and identified as the larval stage of the tick species I. holocyclus from the family of hard ticks, Ixodidae. Histopathological examination revealed deep embedding of the larval tick's mouthparts, with extension into the conjunctival stroma (fig. 2).

\section{Discussion}

Conjunctival attachment of a live tick is a rare occurrence with only 7 cases ( 6 reports) found in the literature [4-9]. The paralysis tick, I. holocyclus, is one of 7 species in the subgenus Sternalixodes, all of which are exclusive to Australia [1]. The paralysis tick is distributed predominantly along the east coast from North Queensland to Southern Victoria, and possibly into Tasmania (fig. 3). Hard ticks, which include the paralysis tick, go through 4 life stages from the egg to larva, to nymph, and finally to the adult stage. From the vegetation where they 'quest' for a host, female ticks attach onto passing vertebrate hosts, including humans, and feed on the blood [10]. Paralysis ticks, including the larval form, have long mouthparts to enable a strong attachment to the host $[1,10]$. Our patient probably came into contact with the larval tick while sitting on grass. The paralysis tick tends to show seasonality in life stages, and the larval stage is most active at this time of the year (summer) in Australia [10].

During blood feeding, ticks transfer saliva, which contains a cocktail of chemicals including toxins, various allergy-inducing proteins, and potentially disease-causing pathogens [1013]. Tick bites to the eye may cause ocular irritation at the attachment site, conjunctivitis, uveitis, keratitis, and vasculitis [2]. Ticks can become embedded in the meibomian gland orifice and cause eyelid swelling and pain [14]. Although rarely reported in humans, toxins transmitted from the paralysis tick's saliva have been associated with ascending motor paralysis, diplopia, blurred vision, and photophobia especially in children [13]. The paralysis tick, however, needs several days of engorgement on its host before these signs of tick paralysis are manifested. This is because adult ticks go through various phases of feeding, including a slow phase, where the production of toxins in the tick's salivary glands is very low on day 1 and 2 of the blood feed, and a rapid phase, where salivary production peaks on day 5 
Teong et al.: Conjunctival Attachment of a Live Paralysis Tick, Ixodes holocyclus, in a Child: A Case Report

$[3,13]$. The timing of these phases varies according to life stage and, typically, larvae feed for a shorter duration. Our patient had a larval tick attached to his conjunctiva for 2 days and has so far not developed any visual or neurological symptoms.

Paralysis ticks are vectors of infectious diseases such as Queensland tick typhus and Flinders Island spotted fever [10]. Tick bites have been associated with Lyme borreliosis, although more conclusive evidence is required to determine that the Borrelia bacteria is present in ticks in Australia [15]. Regarding the larval stage of hard ticks, the Infectious Diseases Society of America (IDSA) does not recommend routine antibiotic prophylaxis due to the low risk of disease transmission [7]. This is because the larval form typically has not previously fed on another host from which they may have acquired a pathogen. Currently, Australia has no antibiotic prophylaxis recommendations for tick bites. However, antibiotic prophylaxis is often given when the tick bite has occurred in a location where infection would have more detrimental consequences, such as the eye [11]. Our patient was started on a 1-week course of oral Cephalexin and Chloramphenicol ophthalmic ointment. He has so far remained systemically well.

Tick allergy has been well documented and ranges from mild urticaria, allergic conjunctivitis, to anaphylaxis. It was recently recognised that patients previously bitten by the paralysis tick may subsequently develop anaphylaxis from the consumption of mammalian meat and meat by-products such as gelatine [11], although this condition has not yet been associated with the larval stage. The mechanism of this is beyond the scope of this paper, but clinicians may consider close monitoring of the patient for hypersensitivity reactions.

There is conflicting opinion about the preferred method of tick removal. Five out of the 7 cases of conjunctival tick attachment had the removal by conjunctival excision (table 1). The reasons for surgical removal were either a firmly attached tick [5-7] or simply that the conjunctiva was involved [4]. One case report proposed that blunt, medium-tipped, angled forceps offered the best result for removing ticks not deeply seated in the conjunctiva [8]. Another case successfully used blunt force with a cotton applicator but admitted difficulty with this approach for embedded ticks [9]. In all 7 cases, recovery of the patient was uneventful, and no parts of the tick remained in the conjunctiva. The Australasian Society of Clinical Immunology and Allergy (ASCIA) recommends first killing an embedded tick with ethercontaining agents or permethrin-based products and then letting it drop off the host or removing it with fine-tipped forceps to avoid squeezing saliva into the host's vasculature [12]. However, ASCIA recognises that this method is not suitable for all patients, especially when the tick is embedded in sensitive areas of the body such as the eye.

Despite the different tick removal methods postulated, there is consensus in the literature that the goal of treatment should be complete removal of the tick from the host to prevent further transmission of pathogens, allergens, and toxins [4-12]. In our patient, application of ether-containing agents to the conjunctiva was not appropriate. The larval tick was too firmly attached to the bulbar conjunctiva, so complete and safe removal of it using forceps was not possible in a conscious child. It is not uncommon for ticks to inject further toxins into the host if disturbed [10]. We decided that conjunctival excision under general anaesthesia was the best option available. The tick was removed completely and our patient has so far not experienced any post-operative complications or systemic illness.

\section{Conclusion}

The goal of treatment for conjunctival tick attachment should be to completely and safely remove the tick as soon as possible to prevent further transmission of pathogens, toxins, 
Teong et al.: Conjunctival Attachment of a Live Paralysis Tick, Ixodes holocyclus, in a Child: A Case Report

and allergens to the patient. Surgical removal of the tick and surrounding conjunctiva (with general anaesthetic if necessary) proved simple and effective with no adverse sequelae, a decision supported by the histopathological examination revealing deep embedding of the tick's mouthparts into the conjunctiva.

\section{Disclosure Statement}

The authors have no conflicts of interest to disclose.

\section{References}

1 Barker S, Walker A, Campelo D: A list of 70 species of Australian ticks; diagnostic guides to and species accounts of Ixodes holocyclus (paralysis tick) Ixodes cornuatus (southern paralysis tick) and Rhipicephalus australis (Australian cattle tick); and consideration of the place of Australia in the evolution of ticks with comments on four controversial ideas. Int J Parasitol 2014;44:941-953.

-2 Ugur K, Kaan U, Alpay C, Sedat A, Nezehat A: Tick infestation of the eyelid: a case report in a child. Turk J Pediatr 2009;51:172-173.

-3 Grattan-Smith PJ, Morris JG, Johnston HM, Yiannikas C, Malik R, Russell R, Ouvrier RA: Clinical and neurophysiological features of tick paralysis. Brain 1997;120:1975-1987.

4 Love MC, Platt L, Westfall CT: Lone-star tick bite of the conjunctiva. Arch Ophthalmol 2001;119:1854-1855.

5 Bode D, Speicher P, Harlan H: A seed tick infestation of the conjunctiva: Amblyomma americanum larva. Ann Ophthalmol 1987;19:63-64.

6 Meades KV, Lam G: Larva tick bite of the conjunctiva. Aust NZ J Ophthalmol 1991;19:365-366.

-7 Willen C, Mullen GR, Yee J, Read RW: Conjunctival attachment of a tick: clinicopathologic report of a case. J Emerg Med 2007;40:41-44.

8 Celik E, Turkoglu EB, Boz AA, Alagoz G: Conjunctival attachment of a tick: case report. Semin Ophthalmol 2014;29:186-188.

-9 Jensen LA, Snow RL, Clifford CM: Spinose ear tick, Otobius megnini, attached to the conjunctiva of a child's eye. J Parasitol 1982;68:528.

10 Department of Medical Entomology, Westmead Hospital: Ticks. Sydney, Westmead Hospital, January 28, 1998 (updated November 7, 2003). http://medent.usyd.edu.au/fact/ticks.htm (accessed February 17, 2015).

11 Nunen S: Tick-induced allergies: mammalian meat allergy, tick anaphylaxis and their significance. Asia Pac Allergy 2015;5:3-16.

12 Australasian Society of Clinical Immunology and Allergy: Tick allergy. Sydney, ASCIA, 2014 (updated January 2014). http://www.allergy.org.au/patients/insect-allergy-bites-and-stings/tick-allergy (accessed February 10, 2015).

13 Hall-Mendelin S, Craig SB, Hall RA, O’Donoghue P, Atwell RB, Tulsiani SM, Graham GC: Tick paralysis in Australia caused by Ixodes holocyclus Neumann. Ann Trop Med Parasito 2011;105:95-106.

14 Singh M, Gopalakrishmakone P, Yeoh RL: Ixodes tick infestation of the eyelid of a child. Can J Ophthalmol 2006;41:783-784.

15 Australian Government Department of Health: Lyme disease. Canberra, Australian Government Department of Health, 2015 (updated August 18, 2014). Progress report against the CACLD terms of reference (July 31, 2014). http://www.health.gov.au/lyme-disease (accessed February 18, 2015). 
Teong et al.: Conjunctival Attachment of a Live Paralysis Tick, Ixodes holocyclus, in a Child: A Case Report

Table 1. Comparison of case reports of conjunctival tick attachment

\begin{tabular}{|c|c|c|c|c|c|c|c|c|}
\hline $\begin{array}{l}\text { Authors } \\
\text { [ref.] }\end{array}$ & Tick species & $\begin{array}{l}\text { Geographic } \\
\text { area }\end{array}$ & $\begin{array}{l}\text { Patient } \\
\text { age, } \\
\text { years }\end{array}$ & Eye & $\begin{array}{l}\text { Location } \\
\text { on con- } \\
\text { junctiva }\end{array}$ & $\begin{array}{l}\text { Stage of } \\
\text { tick } \\
\text { species }\end{array}$ & $\begin{array}{l}\text { Method of } \\
\text { removal }\end{array}$ & $\begin{array}{l}\text { Method of } \\
\text { anaesthesia }\end{array}$ \\
\hline $\begin{array}{l}\text { Love } \\
\text { et al. [4] }\end{array}$ & $\begin{array}{l}\text { Amblyomma } \\
\text { americanum }\end{array}$ & $\begin{array}{l}\text { Arkansas, } \\
\text { USA }\end{array}$ & 5 & OD & temporal & NI & $\begin{array}{l}\text { conjunctival } \\
\text { excision }\end{array}$ & $\begin{array}{l}\text { IV sedation } \\
\text { (ketamine/ } \\
\text { midazolam) }\end{array}$ \\
\hline $\begin{array}{l}\text { Love } \\
\text { et al. [4] }\end{array}$ & $\begin{array}{l}\text { Amblyomma } \\
\text { americanum }\end{array}$ & $\begin{array}{l}\text { Arkansas, } \\
\text { USA }\end{array}$ & 2 & OS & temporal & NI & $\begin{array}{l}\text { conjunctival } \\
\text { excision }\end{array}$ & $\begin{array}{l}\text { IV sedation } \\
\text { (ketamine/ } \\
\text { midazolam) }\end{array}$ \\
\hline $\begin{array}{l}\text { Bode } \\
\text { et al. [5] }\end{array}$ & $\begin{array}{l}\text { Amblyomma } \\
\text { americanum }\end{array}$ & Texas, USA & 28 & OD & $\begin{array}{l}\text { infero- } \\
\text { temporal }\end{array}$ & larval & $\begin{array}{l}\text { conjunctival } \\
\text { excision }\end{array}$ & $\begin{array}{l}\text { local } \\
\text { anaesthesia }\end{array}$ \\
\hline $\begin{array}{l}\text { Meades } \\
\text { and Lam } \\
{[6]}\end{array}$ & Unknown & Australia & 27 & NI & $\mathrm{NI}$ & larval & $\begin{array}{l}\text { conjunctival } \\
\text { excision }\end{array}$ & $\begin{array}{l}\text { local } \\
\text { anaesthesia }\end{array}$ \\
\hline $\begin{array}{l}\text { Willen } \\
\text { et al. [7] }\end{array}$ & $\begin{array}{l}\text { Amblyomma } \\
\text { americanum }\end{array}$ & $\begin{array}{l}\text { Alabama, } \\
\text { USA }\end{array}$ & 39 & OD & nasal & larval & $\begin{array}{l}\text { conjunctival } \\
\text { excision }\end{array}$ & $\begin{array}{l}\text { local } \\
\text { anaesthesia }\end{array}$ \\
\hline $\begin{array}{l}\text { Celik } \\
\text { et al. [8] }\end{array}$ & Ixodes spp & Turkey & 36 & OD & nasal & $\mathrm{NI}$ & $\begin{array}{l}\text { blunt for- } \\
\text { ceps }\end{array}$ & $\begin{array}{l}\text { local } \\
\text { anaesthesia }\end{array}$ \\
\hline $\begin{array}{l}\text { Jensen } \\
\text { et al. [9] }\end{array}$ & $\begin{array}{l}\text { Otobius } \\
\text { megnini }\end{array}$ & $\begin{array}{l}\text { Arizona, } \\
\text { USA }\end{array}$ & 2 & os & $\begin{array}{l}\text { infero- } \\
\text { temporal }\end{array}$ & larval & $\begin{array}{l}\text { blunt force } \\
\text { with cotton } \\
\text { applicator }\end{array}$ & $\mathrm{NI}$ \\
\hline $\begin{array}{l}\text { Current } \\
\text { case }\end{array}$ & $\begin{array}{l}\text { Ixodes } \\
\text { holocyclus }\end{array}$ & $\begin{array}{l}\text { Sydney, } \\
\text { Australia }\end{array}$ & 10 & OD & temporal & larval & $\begin{array}{l}\text { conjunctival } \\
\text { excision }\end{array}$ & $\begin{array}{l}\text { general } \\
\text { anaesthesia }\end{array}$ \\
\hline
\end{tabular}

$\mathrm{OD}$ = Right eye; $\mathrm{OS}$ = left eye; $\mathrm{NI}=$ no information .
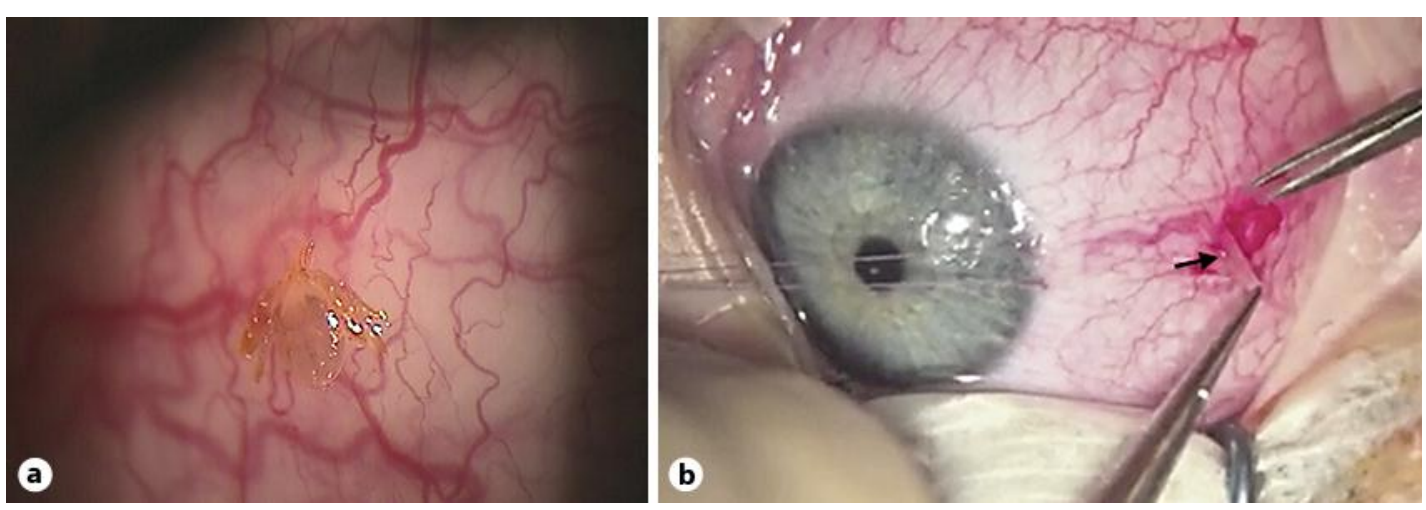

Fig. 1. a Live larval paralysis tick attached to the patient's right temporal bulbar conjunctiva. b Surgical removal of the larval tick and surrounding conjunctiva using Bonn 0.12-mm forceps and straight Vannas scissors. The position of the tick on the conjunctiva is indicated by the black arrow. 


\section{Case Reports in \\ Ophthalmology}

\begin{tabular}{l|l}
\hline \multicolumn{2}{l}{ Case Rep Ophthalmol 2015;6:120-126 } \\
\hline DOI: 10.1159/000381743 & $\begin{array}{l}\text { ○ 2015 S. Karger AG, Basel } \\
\text { www.karger.com/cop }\end{array}$ \\
\hline
\end{tabular}

Teong et al.: Conjunctival Attachment of a Live Paralysis Tick, Ixodes holocyclus, in a Child: A Case Report

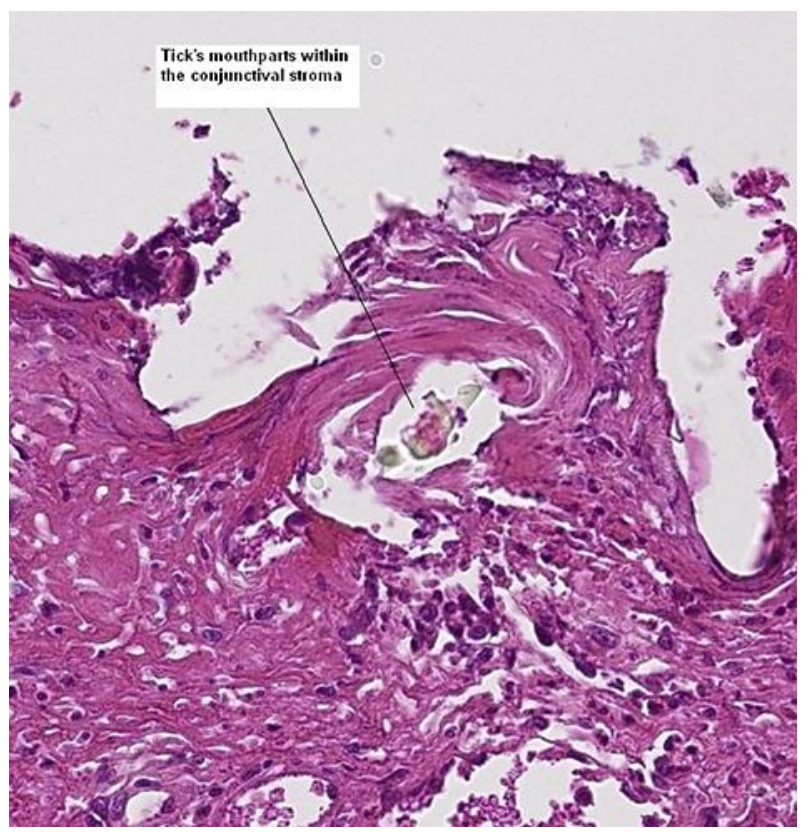

Fig. 2. Biopsy of tissue excised from the right temporal conjunctiva showing mouthparts of the tick within stroma. 
Case Reports in

Ophthalmology

\begin{tabular}{l|l}
\hline \multicolumn{2}{l}{ Case Rep Ophthalmol 2015;6:120-126 } \\
\hline DOI: 10.1159/000381743 & $\begin{array}{l}\text { ○ 2015 S. Karger AG, Basel } \\
\text { www.karger.com/cop }\end{array}$ \\
\hline
\end{tabular}

Teong et al:: Conjunctival Attachment of a Live Paralysis Tick, Ixodes holocyclus, in a Child: A Case Report

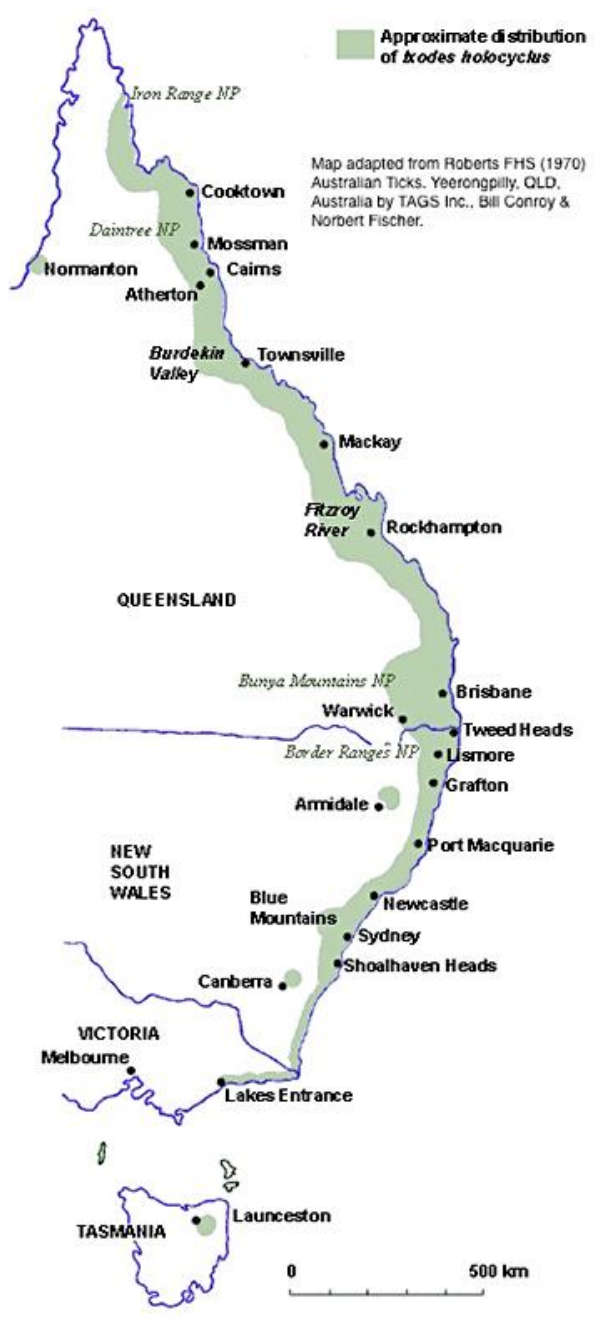

Fig. 3. Approximate distribution of the paralysis tick, I. holocyclus, in Australia. 